\title{
SISTEM PENDUKUNG KEPUTUSAN PEMILIHAN LOKASI STRATEGIS CABANG USAHA WARUNG MAKANAN
}

\author{
Dodo Zulkarnain ${ }^{1}$, Yan Watequlis Syaifudin ${ }^{2}$, Cahya Rahmad ${ }^{3}$ \\ ${ }^{1}$ Mahasiswa Jurusan Teknologi Informasi Politeknik Negeri Malang, ${ }^{2,3}$ Dosen Jurusan Teknologi Informasi \\ Politeknik Negeri Malang \\ Email: ${ }^{1}$ dodozulkarnain29@gmail.com, ${ }^{2}$ qulis@polinema.ac.id, ${ }^{3}$ cahya_rahmad@yahoo.com
}

\begin{abstract}
Abstrak
Perkembangan semakin cepat di bidang teknologi semakin banyak cara manusia untuk menggunakan teknologi tersebut. Salah satu adalah sistem pendukung keputusan. Sistem pendukung keputusan adalah sistem yang mampu memberikan kemampuan pemecahan masalah maupun kemampuan pengkomunikasian untuk masalah dengan kondisi semi terstruktur dan tak terstruktur.Sistem pendukung keputusan yang baik adalah yang dapat membantu memecahkan pilihan yang tidak terstruktur menjadi terstruktur. Dengan adanya itu pemilihan lokasi strategis dapat membantu usaha warung makanan yang akan membuka cabang baru. Kelayakan lokasi terkadang hanya dikira-kira atau hanya memikirkan saja tanpa adanya perhitungan. Maka dari itu dibutuhkan sistem pendukung keputusan pemilhan lokasi strategis untuk membuka cabang usaha warung makanan dengan menggunakan metode AHP (analytical hierarchy process).Metode AHP (analytical hierarchy process) adalah metode untuk memecahkan suatu situasi yang komplek tidak terstruktur ke dalam beberapa komponen dalam susunan yang hirarki dengan memberi nilai subjektif tentang pentingnya setiap variabel secara relatif dan menetapkan variabel mana yang memiliki prioritas paling tinggi guna mempengaruhi hasil pada situasi tersebut. Hasil akhir tersebut berbentuk rekomendasi-rekomendasi lokasi-lokasi strategis untuk membuka cabang baru yang diharapkan membantu para pengusaha menentukan lokasi cabang baru. Selain itu seleksi lokasi yang dilakukan dengan aplikasi ini dapat memberikan hasil cukup akurat, hal ini terbukti dengan pengujian yang telah dilakukan dari perbandingan seleksi manual dan seleksi sistem dengan keakuratan 99,8\%.
\end{abstract}

Kata kunci : Sistem pendukung keputusan, Lokasi strategis, AHP.

\section{Pendahuluan}

Kini banyak sekali pengusaha makanan yang bermunculan terutama di kota-kota besar. Seiring dengan banyaknya usaha yang didirikan maka semakin banyak pula persaingan dalam memikat konsumen, salah satu faktornya adalah pemilihan tempat lokasi yang tepat dan strategis. Kadangkala pemilik usaha kurang memperhatikan faktor-faktor penunjang tersebut sehingga cabang usaha makanan yang dibuka tidak seramai usaha makanan lainnya yang telah berdiri sebelumnya.

Banyaknya mahasiswa luar kota juga menambahkan konsumen terutama di kota malang. Mahasiswa yang berdatangan ke kota malang merupakan faktor utama untuk membuka cabang usaha makanan salah satunya di griya bebek dan ayam nelongso. Griya bebek dan ayam nelongso telah membuka 6 cabang warung makanan yaitu JI Soekarno Hatta Indah 4A Malang, Jl. Soekarno Hatta 3B Malang, Jl. Bendungan Sutami 3A Malang, Jl. Raya Mulyo Agung 2A Dau Malang dan J1. Bendungan Sigura-Gura Barat Malang dan akan merencanakan untuk menambah cabang warung makanan 20 cabang di akhir 2016 selain di kota malang ataupun di kota malang ini.Di griya bebek dan ayam nelongso Setiap cabang yang telah dibuka membuka minat untuk konsumen mencicipi bebek dan ayam tersebut tetapi untuk menentukan sebuah tempat cabang sering kali mengalami kesulitan untuk memperhitungkan tempat yang strategis dan cocok untuk griya bebek dan ayam nelongso. Oleh karena itu, untuk pemilihan tempat lokasi untuk usaha warung makanan yang strategis dan tepat adanya kriteria-kriteria akan semakin memperkuat untuk pemilihan tempat lokasi untuk membuka cabang usaha griya bebek dan ayam nelongso.

Berawal dari itu, peneliti akan membuat sistem pedukung keputusan pemilihan lokasi untuk membuka cabang usaha warung makanan di Griya bebek dan Ayam Nelongso. Sistem pendukung keputusan adalah untuk mengumpulkan data, menganalisa dan membentuk data yang dikoleksi, dan mengambil keputusan yang benar atau membangun strategi dari analisis, tidak pengaruh terhadap computer, basis data atau manusia penggunanya. Dengan adanya sistem ini proses hasil output tersebut akan menampilkan informasi berupa rekomendasi-rekomendasi lokasi-lokasi 
untuk membuka cabang usaha warung makanan yang strategis dan tepat.

\section{Tinjaun Pustaka}

\subsection{Sistem pendukung keputusan}

Sistem Pendukung Keputusan (SPK) atau Decision Support System (DSS) adalah sebuah sistem yang mampu memberikan kemampuan pemecahan masalah maupun kemampuan pengkomunikasian untuk masalah dengan kondisi semi terstruktur dan tak terstruktur. Sistem ini digunakan untuk membantu pengambilan keputusan dalam situasi semi terstruktur dan situasi yang tidak terstruktur, dimana tak seorangpun tahu secara pasti bagaimana keputusan seharusnya dibuat (Turban, 2001).

SPK bertujuan untuk menyediakan informasi, membimbing, memberikan prediksi serta mengarahkan kepada pengguna informasi agar dapat melakukan pengambilan keputusan dengan lebih baik.

\subsection{Ruko}

Ruko dapat dibagi menjadi beberapa jenis berikut penjelasannya:

1. Berdasarkan tipologi bangunan

a. Tunggal

Tipe ini memiliki wujud bangunan tunggal dengan satu unit ruko yang berada dalam sepetak lahan tau satu bangunan ruko yang terbagi menjadi beberapa unit ruko didalamnya dan berada dalam satu blok lahan yang cukup besar.

b. Deret

Tipe ini memiliki wujud bangunan yang berderet yang sisi kanan dan kirinya menempel dengan ruko disampingnya.

2. Berdasarkan Pihak Pembangunan Ruko ini juga menjadi lahan investasi yang menggiurkan.itu alasan semakin banyak ruko yang dibangun pengusaha ruko, dari berskala kecil, menengah, sampai besar, termasuk pengembangan.

3. Berdasarkan dari pengusaha berskala kecil hingga menengah

Biasanya berjumlah satu sampai tiga unit ruko yang berlokasi di pinggir jalan. Karena luas lahanyatidak besar, fasilitas parkir juga terbatas maka banyak dipakai pemiliknya sendiri sebagai tempat usaha.

4. Berdasarkan dari pengusaha berskala menengah hingga besar

Biasanya berlokasi di areal yang cukup luas di pinggir jalan. Umumnya terdiri atas empat sampai sepuluh unit ruko. Memiliki areal parkir di depan ruko dengan daya tamping kendaran yang beragam, tergantung luas lahanya.

5. Berdasarkan dari pengembangan
Biasanya berupa kompleks ruko didalam areal perumahan yang juga dibangun untuk pengembangan tersebut. Jumlah ruko dalam satu kompleks yang dibangun pengembang bias mencapai puluhan hingga ratusan.

\subsection{AHP (Analytical hierarchy process)}

Analytic Hierarchy Process (AHP) adalah metode untuk memecahkan suatu situasi yang komplek tidak terstruktur ke dalam beberapa komponen dalam susunan yang hirarki dengan memberi nilai subjektif tentang pentingnya setiap variabel secara relatif dan menetapkan variabel mana yang memiliki prioritas paling tinggi guna mempengaruhi hasil pada situasi tersebut.

Proses pengambilan keputusan pada dasarnya adalah memilih suatu alternatif yang terbaik. Seperti melakukan penstrukturan persoalan, penentuan alternatif-alternatif, penenetapan nilai kemungkinan untuk variabel random, persyaratan preferensi terhadap waktu dan spesifikasi atas resiko. Berapapun melebarnya alternatif yang dapat ditetapkan maupun terperincinya penjajagan nilai kemungkinan, keterbatasan yang tetap terjaga adalah dasar pembandingan berbentuk suatu kriteria yang tunggal. Peralatan utama Analytic Hierarchy Process (AHP) adalah memiliki sebuah hirarki fungsional dengan persepsi manusia sebagai input utamanya. Dengan adanya hirarki, maka suatu masalah kompleks dan tidak terstruktur dapat dipecah ke dalam kelompok-kelompok yang kemudian diatur menjadi suatu bentuk hirarki.

\section{Metodelogy}

\subsection{Pengolahan Data}

Dalam tahapan ini akan diformulasikan model yang akan digunakan serta memasukkan kriteria dan subkriteria yang akan dimasukkan kedalam formulasi model ini. Model yang akan diterapkan adalah metode AHP (analytical hierarchy process). Tujuan yang dicapai oleh sistem ini adalah membantu menentukan lokasi strategis untuk membuka cabang usaha warung makanan di griya bebek dan ayam nelongso. Berikut formulasi model untuk metode AHP:

1. Menentukan nilai intensitas perbandingan kriteria yang telah ditentukan oleh skala saaty

2. Mejumlahkan kolom pada hasil nilai intensitas perbandingan kriteria.

3. Menormalisasikan tiap elemen dengan membagi tiap elemen kolom dengan jumlah kolom

4. Menjumlahkan baris pada hasil normalisasi

5. Menentukan nilai eigen vector normalisasi dengan membagi jumlah baris normalisasi dan jumlah kriteria 
Penetapan Prioritas Elemen dengan Perbandingan Berpasangen

\begin{tabular}{|c|l|l|}
\hline $\begin{array}{c}\text { Intensitas } \\
\text { Kepentingan }\end{array}$ & \multicolumn{1}{|c|}{ Keterangan } & \multicolumn{1}{|c|}{ Penjelasan } \\
\hline 1 & $\begin{array}{l}\text { Kedua elemen sama } \\
\text { pentingnya }\end{array}$ & $\begin{array}{l}\text { Dua elemen mempunyai pengaruh } \\
\text { yang sama besar terhadap tujuan }\end{array}$ \\
\hline 3 & $\begin{array}{l}\text { Elemen yang satu sedikit } \\
\text { lebih penting daripada } \\
\text { elemen yang lainnya }\end{array}$ & $\begin{array}{l}\text { Pengalaman dan penilaian sedikit } \\
\text { menyokong satu elemen } \\
\text { dibandingkan elemen lainnya }\end{array}$ \\
\hline 5 & $\begin{array}{l}\text { Elemen yang satu lebih } \\
\text { penting daripada elemen } \\
\text { yang lainnya. }\end{array}$ & $\begin{array}{l}\text { Pengalaman dan penilaian sangat } \\
\text { kuat menyokong satu elemen } \\
\text { dibandingkan elemen lainnya }\end{array}$ \\
\hline 7 & $\begin{array}{l}\text { Satu elemen jelas lebih } \\
\text { mutlak penting daripada } \\
\text { elemen lainnya }\end{array}$ & $\begin{array}{l}\text { Satu elemen yang kuat disokong } \\
\text { dan dominan terlihat dalam praktek }\end{array}$ \\
\hline $2,4,6,8$ & $\begin{array}{l}\text { Satu elemen mutlak penting } \\
\text { daripada elemen lainnya }\end{array}$ & $\begin{array}{l}\text { Bukti yang mendukung elemen } \\
\text { yang satu terhadap elemen lain } \\
\text { memiliki tingkat penegasan } \\
\text { tertinggi yang mungkin } \\
\text { menguatkan }\end{array}$ \\
\hline Kebalikan & $\begin{array}{l}\text { Nilai-nilai antara dua nilai } \\
\text { pertimbangan yang } \\
\text { berdekatan }\end{array}$ & $\begin{array}{l}\text { Nilai ini diberikan bila ada dua } \\
\text { kompromi diantara dua pilihan }\end{array}$ \\
\hline $\begin{array}{l}\text { Jika untuk aktivitas I mendapat satu angka dibanding dengan } \\
\text { i. }\end{array}$
\end{tabular}

Gambar 1 Skala saaty

6. Menentukan nilai eigen maks dengan menjumlahkan hasil perkalian jumlah kolom dengan nilai eigen vector normalisasi

7. Menentukan nilai indeks konsistensi

$$
C I=\frac{\left(\lambda_{\max }-n\right)}{(n-1)}
$$

8. Menentukan nilai rasio konsitensi, jika $>0.1$ maka tidak konsisten

\section{Consistency Ratio}

$$
=\frac{\text { Consistency Index }}{\text { Random Index }}
$$

\begin{tabular}{|l|l|l|l|l|l|l|l|l|l|l|l|l|l|l|}
\hline Lkuran matriks & 1,2 & 3 & 4 & 5 & 6 & 7 & 8 & 9 & 10 & 11 & 12 & 13 & 14 & 15 \\
\hline
\end{tabular}

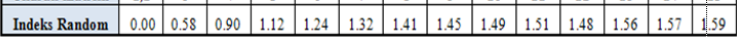

\section{Gambar 2 nilai indeks random}

9. Menentukan nilai intensitas perbandingan subkriteria yang ditentukan oleh skala saaty

10. Mejumlahkan kolom pada hasil nilai intensitas perbandingan subkriteria.

11. Menormalisasikan tiap elemen dengan membagi tiap elemen kolom dengan jumlah kolom

12. Menjumlahkan baris pada hasil normalisasi

13. Menentukan nilai eigen vector normalisasi dengan membagi jumlah baris normalisasi dan jumlah subkriteria

14. Menentukan nilai bobot alternative

\subsection{Metodelogi Penelitian}

Metode penelitian dalam skripsi ini menggunakan SDLC (System Development Life Cycle) yaitu proses logis yang digunakan oleh analis sistem untuk menggambarkan sebuah sistem informasi, termasuk di dalamnya persyaratan, validasi, pelatihan dan kepemilikan. SDLC merupakan siklus pengembangan sistem. Pengembangan sistem teknik (engineering system development). Meliputi langkah berikut:

1. Perencanaan

Dari hasil pengamat dan wawancara dengan pemilik griya bebek dan ayam nelongso sudah membuka 6 lokasi cabang baru usaha makanan. Seiring dengan banyaknya konsumen atau peminat maka pemilik griya bebek dan ayam nelongso membuka cabang baru usaha warung makanan. pemilik juga akan membuka cabang baru tersebut sebanyak 20 lokasi yang akan tersebar di kota-kota yang sudah dipilih dan membantu pemilik griya bebek dan ayam nelongso untuk memilih lokasi strategis menurut kriteria dan subkriteria yang ditentukan oleh pemilik. Dengan adanya tersebut maka akan akan dibuatkan sistem pendukung keputusan pemilihan lokasi strategis untuk membuka cabang usaha warung makanan.

Untuk mengolah kriteria dan subkriteria dibutuhkan perhitungan metode ahp. Dengan adanya metode tersebut dapat menghasilkan beberapa perankinga alternatif.

2. Analisa sistem

\begin{tabular}{|c|c|c|c|}
\hline No & Kriteria & Sub Kriteria & Range \\
\hline \multirow[t]{4}{*}{1} & Harga & & \\
\hline & & Murah & Rp. $45.000 .000-70.000 .000$ \\
\hline & & Standart & $\begin{array}{l}\text { Rp. } \quad 70.000 .000 \\
145.000 .000\end{array}$ \\
\hline & & Mahal & Lebih dari Rp.146.000.000 \\
\hline 2 & Lantai Ruko & & \\
\hline & & 1 Lantai & Terdapat 1 lantai \\
\hline & & 2 Lantai & Terdapat 2 lantai \\
\hline & & 3 lantai & Terdapat lebih dari 3 lantai \\
\hline \multirow[t]{4}{*}{3} & Luas Ruko & & \\
\hline & & Kecil & Luas $40 \mathrm{~m}^{2}$ sampai $60 \mathrm{~m}^{2}$ \\
\hline & & Sedang & Luas $61 \mathrm{~m}^{2}$ sampai $80 \mathrm{~m}^{2}$ \\
\hline & & Besar & $\begin{array}{l}\text { Luas Lebih dari } 81 \mathrm{~m}^{2} \\
\end{array}$ \\
\hline \multirow[t]{4}{*}{4} & $\begin{array}{l}\text { Persaingan } \\
\text { Sekitar }\end{array}$ & & \\
\hline & & Sedikit & Adanya 1 sampai 4 usaha \\
\hline & & $\begin{array}{l}\text { Lumayan } \\
\text { L }\end{array}$ & Adanya 5 sampai 8 usaha \\
\hline & & Banyak & Adanya lebih dari 9 usaha \\
\hline
\end{tabular}

Tabel 1 Data kriteria dan subkriteria 


\begin{tabular}{|c|c|c|c|}
\hline 5 & $\begin{array}{ll}\text { Luas } & \text { Lahan } \\
\text { Parkir } & \end{array}$ & & \\
\hline & & Kecil & Luas $10 \mathrm{~m}^{2}$ sampai $25 \mathrm{~m}^{2}$ \\
\hline & & Sedang & Luas $26 \mathrm{~m}^{2}$ sampai $40 \mathrm{~m}^{2}$ \\
\hline & & Lumayan & Luas Lebih dari $41 \mathrm{~m}^{2}$ \\
\hline 6 & $\begin{array}{l}\text { Akses } \\
\text { transportasi } \\
\text { umum }\end{array}$ & & \\
\hline & & Sedang & $\begin{array}{llll}\begin{array}{l}\text { Terdapat } \\
\text { transportasi }\end{array} & 1 & \text { sampai } & 6\end{array}$ \\
\hline & & Lumayan & $\begin{array}{llll}\begin{array}{l}\text { Terdapat } \\
\text { transportasi }\end{array} & \text { sampai } & 10 \\
\end{array}$ \\
\hline & & Banyak & $\begin{array}{l}\begin{array}{l}\text { Terdapat lebih } \\
\text { transportasi }\end{array}\end{array}$ \\
\hline
\end{tabular}

3. Perancangan

Perancangan sistem pada tahap dimana penulis mulai merancang suatu sistem yang mampu memenuhi semua kebutuhan fungsional aplikasi dalam tugas akhir ini. Teori-teori dari pustaka dan data dari sample digabungkan dengan ilmu yang didapat diimplementasikan untuk merancang serta mengembangkan suatu sistem pendukung keputusan pemilihan lokasi strategis untuk membuka cabang usaha warung makanan. Perancangan sistem terdiri dari perancangan subsistem manajemen berbasis pengetahuan, subsistem manajemen data, dan subsistem Model.

4. Implementasi

Implementasi sistem yang menerapkan metode AHP dilakukan berdasarkan perancangan sistem. Implementasi perangkat lunak dilakukan dengan menggunakan bahasa pemrograman PHP dengan database mysql dengan aplikasi xampp. Implementasi sistem meliputi:

a. Pembuatan interface

b. Melakukan perhitungan AHP untuk menentukan bobot kriteria

c. Melakukan perhitungan AHP untuk menentukan bobot subkriteria

d. Menghasilkan nilai bobot alternatif yang dimasukkan

e. Dari nilai bobot alternatif tersebut dapat menunjukkan lokasi yang dipilih berdasarkan nilai bobot kriteria dan subkriteria

5. Pemiliharaan

Ada 3 alasan perlunya pemeliharaan sistem, yaitu:

a. Untuk membenarkan kesalahan atau kelemahan sistem yang tidak terdeteksi pada saat pengujian.

b. Untuk membuat sistem up to date
c. Untuk
meningkatkan kemampuan sistem

\section{Analisis dan perancangan}

4.1 Desain sistem

1. Usecase

UseCase diagram adalah diagram yang menyajikan interaksi antara usecase dan aktor. Dimana aktor dapat berupa orang, peralatan atau sistem lain yang berinteraksi dengan sistem yang sedang dibangun. Use case menggambarkan fungsionalitas sistem atau persyaratan-persyaratan yang harus dipenuhi sistem dari pandanan pemakai. Berikut ini adalah usecase dan deskripsi masing-masing usecase dari Pengembangan Sistem Pendukung keputusan pemlihan lokasi strategis untuk membuka cabang usaha warung makanan:

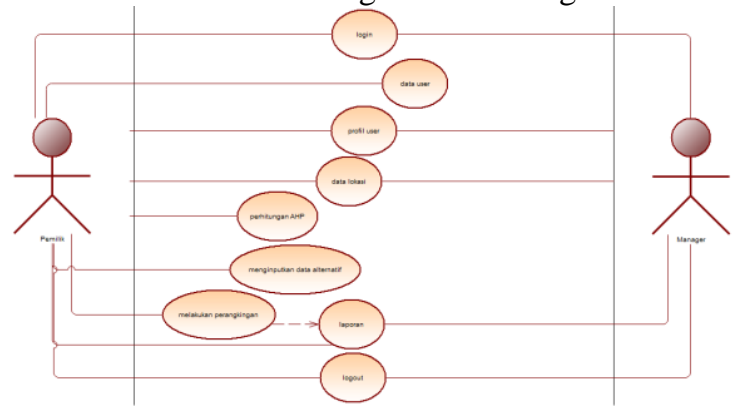

Gambar 3 usecase

\section{ERD}

Sistem ini menggunakan basis data dalam penyimpanannya. Pada basis data tersebut terdapat beberapa tabel yang digunakan untuk menyimpan data yang berhubungan dengan aplikasi sistem. Perancangan ERD dalam penelitian ini menunjukkan entitas apa saja yang terkait, bagaimana relasi yang terjadi, bagaimana cardinality ratio-nya yang akan ditunjukkan pada gambar berikut:

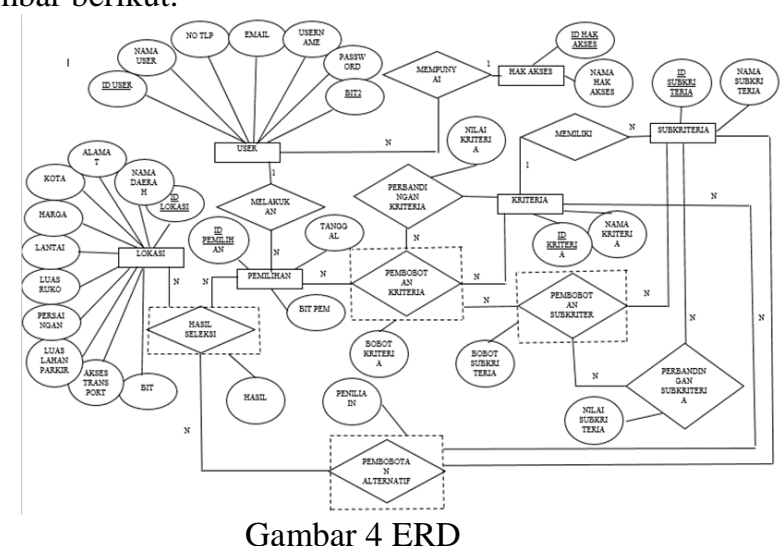

5. Implementasi sistem

5.1 implementasi database 
Pada sub-bab ini akan dijelaskan mengenai implementasi dari basis data yang digunakan. Berdasarkan perancangan basis data yang telah dilakukan oleh penulis, sebagai berikut:

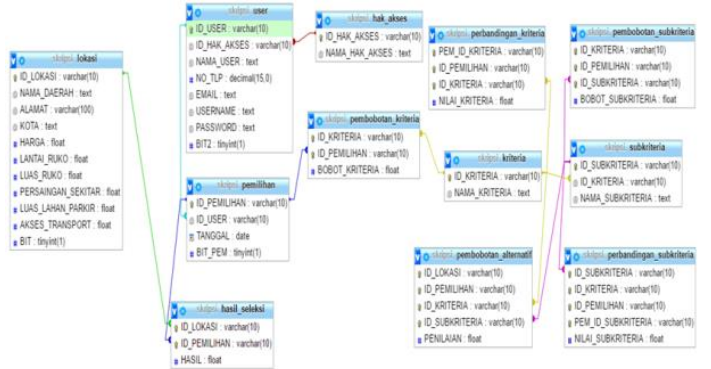

Gambar 5 database sistem

\section{2 implementasi sistem}

Implementasi sistem merupakan tahap penerapan atau pembuatan sistem berdasarkan rancangan yang di lakukan pada bab sebelumnya. Berikut merupakan Implementasi pada sistem yang telah di bangun

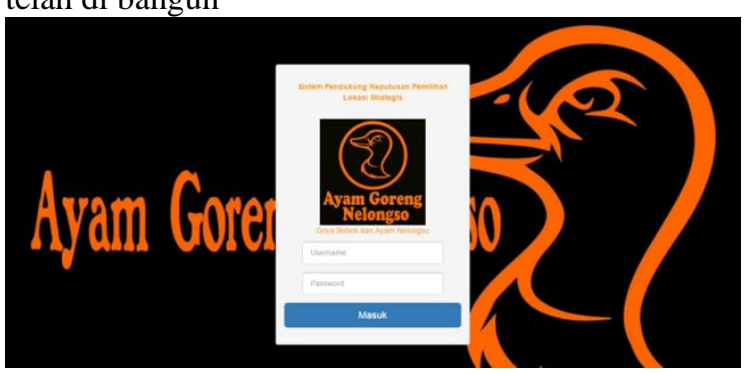

Gambar 6 halaman login

Pada halaman ini pemilik dan manager dapat masuk ke halaman selanjutnya dengan mengisikan username dan password.

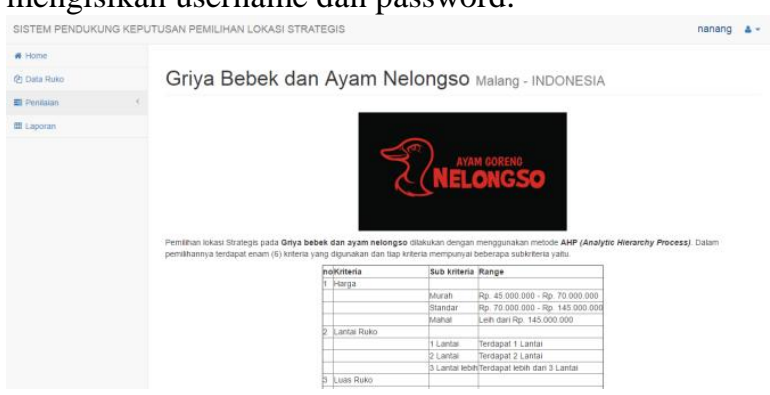

Gambar 7 halaman pemilik pemilik.

Pada halaman ini adalah halaman utama

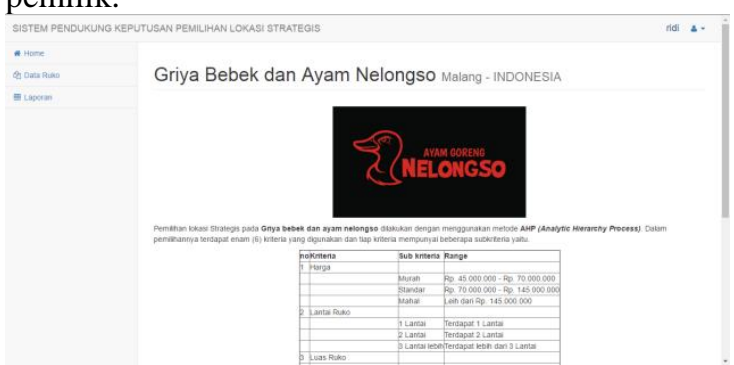

Gambar 8 halaman manager
Pada halaman ini adalah halaman utama manager.

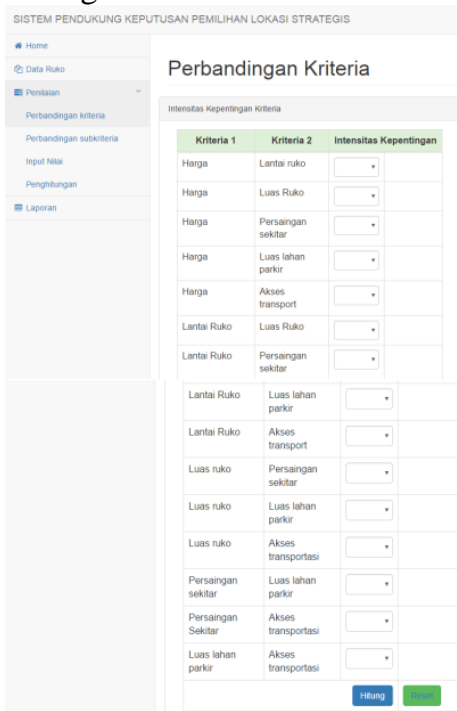

Gambar 9 halaman perbandingan kriteria

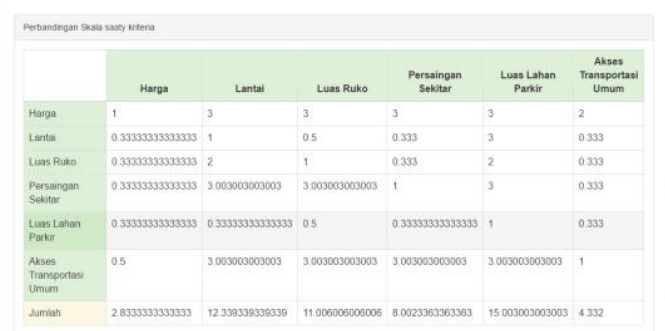

Gambar 10 nilai perbandingan kriteria

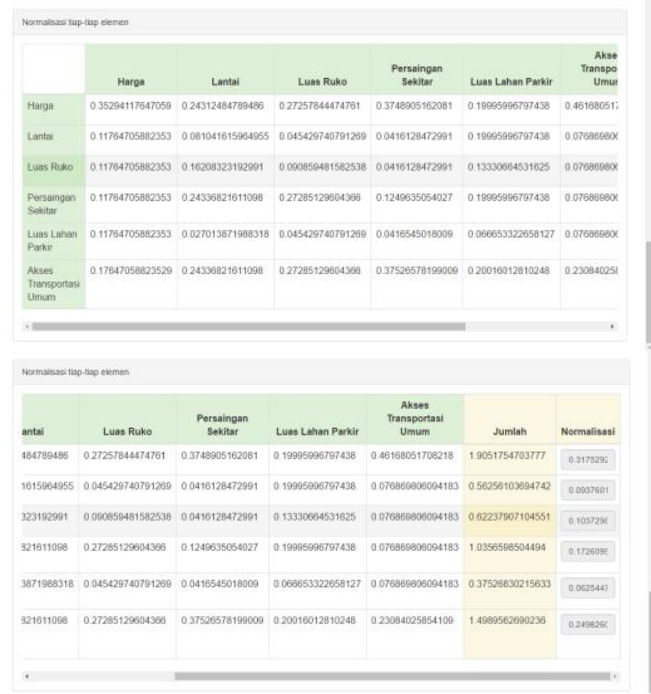

Gambar 11 nilai normalisasi 


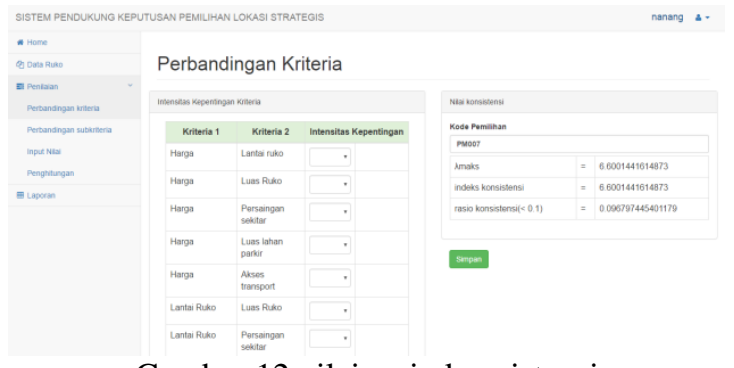

Gambar 12 nilai rasio konsistensi

Pada halaman ini pemilik dapat memasukkan nilai perbandingan kriteria dan pembobotan kriteria.jika nilai rasio konsistensi kurang dari 0.1 maka nilai tersebut konsisten.

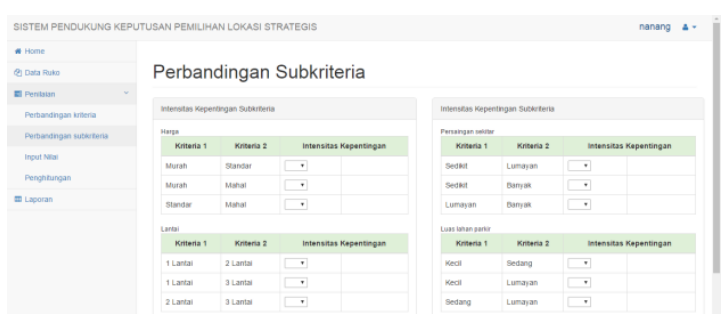

Gambar 13 nilai intensitas perbandingan subkriteria

Pada halaman ini pemilik dapat mengisikan nilai skala saaty agar mendapatkan nilai perbandingan subkriteria dan pembobotan subkriteria.

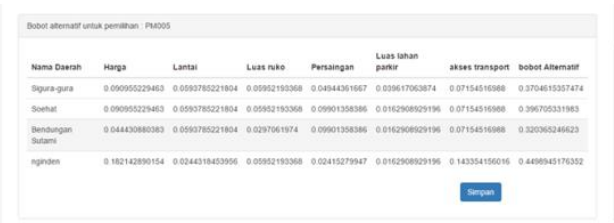

Gambar 14 nilai bobot alternative

Pada halaman ini pemilik dapat menghitungkan data alternatif untuk menghasilkan nilai bobot alternatif tiap data lokasi yang dimasukkan ke dalam pemilihan. Dari nilai bobot alternatif nantinya akan dijadikan perangkingan untuk tiap lokasi.

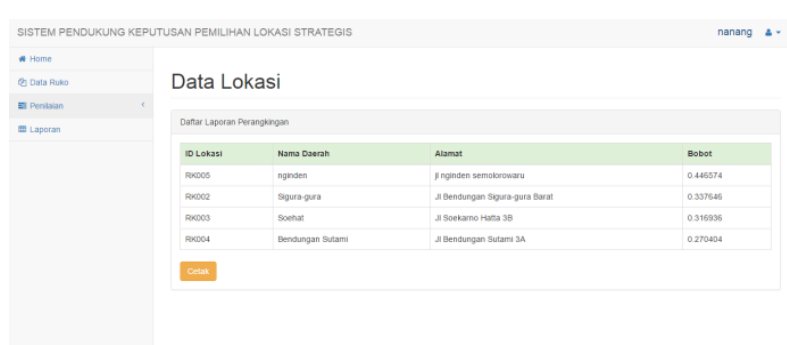

Gambar 15 perangkingan

\section{Pengujian}

Pada bab pengujian dan pembahasan ini akan dilakukan tahapan untuk menguji hasil dari implementasi sistem yang telah dilakukan.

\section{Pembahasan hasil}

Hasil perbandingan perhitungan manual dan perhitungan sistem dalam penentuan bobot dapat di lihat dari tabel beriku:

Tabel 2 pengujian akurasi

\begin{tabular}{|c|c|c|c|c|}
\hline No & Lokasi & Nilai Manual & $\begin{array}{l}\text { Nilai } \\
\text { Sistem }\end{array}$ & Akurasi \\
\hline 1 & $\begin{array}{l}\text { Ruko Klampis } \\
21\end{array}$ & 0.361707387 & 0.361717 & $99 \%$ \\
\hline 2 & Ruko este square & 0.360140575 & 0.360146 & $100 \%$ \\
\hline 3 & $\begin{array}{l}\text { Ruko raya } \\
\text { ngagel madya }\end{array}$ & 0.336936348 & 0.336942 & $100 \%$ \\
\hline 4 & $\begin{array}{l}\text { Ruko } \\
\text { semolowaru }\end{array}$ & 0.30861522 & 0.308606 & $99 \%$ \\
\hline 5 & $\begin{array}{ll}\text { Ruko darmo } \\
\text { galeria }\end{array}$ & 0.236146933 & 0.236149 & $100 \%$ \\
\hline & \multicolumn{3}{|c|}{ Rata-rata } & $99.6 \%$ \\
\hline
\end{tabular}

Pada hasil diatas bahwa keakuratan sistem pendukung keputusan pemilihan lokasi strategis untuk membuka cabang usaha warung makanan adalah rata-rata 99,6\%. Dari hasil tersebut sistem ini layak dijadikan dan dapat membantu membuat keputusan pemilihan lokasi strategis untuk membuka cabang baru warung makanan.

\section{Kesimpulan dan saran}

\subsection{Kesimpulan}

Berdasarkan pembahasan yang ditulis dalam laporan skripsi ini maka dapatditarik beberapa kesimpulan yaitu:

a. Sistem yang dibuat telah dapat membuat nilai konsistensi untuk bobot kriteria yang dihitung dengan metode AHP

b. Sistem yang dibuat berhasil menampilkan hasil perangkingan yang dapat membantu pemilik memilih lokasi strategis untuk cabang baru usaha makanan

c. Sistem yang dibuat layak digunakan untuk membantu pemilihan lokasi strategis, karena telah diuji hasil keakuratan rata-rata $99 \%$ 


\section{Daftar Pustaka:}

Akmal, Imelda.2014. Ruko dan Rukan,cermat sebelum berinvestasi. Jakarta: PT Gramedia Pustaka Utama

Exa, Febri.2015. Pengertian Analytic Hierarchy Process (AHP). [Online] Tersedia: http://vebryexa.com/pengertian-analytichierarchy-process-ahp.html.[6 desember 2015]

Dewanto, joko.2004." SYSTEM DEVELOPMENT LIFE CYCLE DENGAN BEBERAPA PENDEKATAN ". Jurnal FASILKOM.2(1).3947

Sidik, Betha.2014. Pemrograman Web dengan PHP. Bandung: Informatika Bandung

Sparague, R. H. and Watson H. J. 1993. Decision Support Systems: Putting Theory Into Practice. Englewood Clifts, N. J., Prentice Hall.

Sugianto. Candra, Wahyu.(2015). Sistem Pendukung Keputusan Rekomendasi Pengangkatan Karyawan Pesserta Training Menggunakan Metode Analytical Hierarchy Process (AHP) di PT. XYZ. Seminar Nasional "Inovasi dalam Desain dan Teknologi", ISSN: 2089-1121, Universitas Islam Mojopahit mojokerto.

Turban, Efraim \& Aronson, Jay E. 2001. Decision Support Systems and Intelligent Systems. 6th edition. Prentice Hall: Upper Saddle River, NJ.

Tyas.2012. Langkah-langkah Metode AHP. [Online] Tersedia: http://informatika.web.id/langkah-langkahmetode-ahp.htm. [6 desember 2015]

Etunas.2013. Pengertian MySQL. [Online] Tersedia:

http://www.etunas.com/web/pengertianmysql.htm. [14 desember 2015] 